\title{
CORPORATE SOCIAL RESPONSIBILITY AND EMPLOYER ATTRACTIVENESS
}

\author{
Potskhverashvili, Ana
}

\begin{abstract}
As the global competitiveness accelerates in the world, it is a major challenge for the companies to attract talents and attain them within the company. The business needs to contribute to the well-being of the community and society they affect. High salary alone is no longer effective tool for the business, people want to work in the company whose values match their own values and that impact contribute to society and environment. For the business is crucial to know what kind of aspects influence on a particular group of stakeholder (job seekers and employees) decision to choose a place of work. The core research statement is, how CSR based factors influence on employer attractiveness and how these factors impact on the choice of employees in choosing a company for working.

This study is exploratory, a quantitative approach is applied. Questionnaire examines interest of one of the stakeholders, particularly employees' or prospective employees' perception toward company CSR.

According to the results, CSR dimensions (economic, social and environment) were measured by the respondents as highly important for an organization. However, at what extent CSR can be considered as the strongest tool for attracting new talents in the organization and keeping them for a long period is difficult to be measured. Taking into consideration other determinants on employer attractiveness, CSR alone can not attract and attain talents in the organization, but can be one strong determinant that could encourage workers to stay committed to the organization.
\end{abstract}

Keywords: Corporate Social Responsibility, stakeholder theory, CSR-dimensions, employer attractiveness 


\section{Introduction}

Corporate Social Responsibility (CSR) is the main part of the sustainable development, because the CSR regulation sets a broad framework and gives direction for better sustainable future, in practice the companies besides their business activities make quite a big effort to preserve their local environment and have excellent relationships with the local community and the society (Kiss at.al, 2012). Corporations throughout the years have acknowledged that they can no longer operate as "isolated economic entities" detached from the around societies.

The importance and necessity of Corporate Social Responsibility within the company gets very visible in the labor market communication. Managers can admit that the business's success is based on positive relationship with different stakeholders, groups and society at large.

There are results reveals that the value preferences of the managers have their impact on the CSR activities of the company and hence certain main values of the individual determine the practice of the CSR. There is the group of leaders (25\%) could be distinguished who consider CSR as a competitive advantage. These leaders are considered to be leaders with modern CSR viewpoint (Benedek, 2017).

It is obvious that the companies should contribute to the well-being of the communities and society they affect. There is a very high demand of CSR business discipline as the global competitiveness is increasing rapidly in the world and in this situation every business's social and environmental activities must be aligned with its purpose and values. If the companies do so, CSR activities mitigate risks, increase brand reputation and contribute to business results.

By the social identity theory (Turban\&Greening, 1996) it is proved that the firms which are engaged in CSR activities have better image and job seekers are more excited to becoming members of CSR friendly company. For every company is very crucial to know what kind of factors influence on the prospective employees or existing employees' choice to attract them and attain them in the company. By identifying this, the management can take some actions to make the workplace better for employees.

\section{Material and methods}

The study is exploratory, with a quantitative approach. For the purpose of the methodology, quantitative (Questionnaire) approach is applied. Questionnaire examines interest of one of the stakeholders, particularly employees' or prospective employees' perception toward company CSR. The Questionnaire covers a general perception 
and awareness of CSR topic, then follows employer attractiveness determinants. Firstly, CSR based awareness questions were applied in the questionnaire, then CSRbased employer attractiveness questions were followed, where they were asked to rate different determinants that might influence on employer choice on a 5-point Likert type scale ( 1 strongly disagree and 5 strongly agree). The survey also contained some demographic questions. All the scores used for the measures were constructed as means of the factors included. The empirical data was gathered through questions-based questionnaire and literature review.

Several research emphasize that there are differences among the CSR-practies in the different in the varieties of capitalism (Benedek, at al. 2014). It was the reason that I want to research the CSR in my country, in Georgia. The sample size for the survey were 200 people, the majority of the respondents were millenials, so called Georgian Y generation, the most sensitive age group toward ethical issues.

Georgia is one of the countries where the capitalist breakthrough has happened and I wanted to explore what kind of possibilities, opportunities offer this economic system for corporations to be socially responsible.

\section{Results}

In this section was studied the respondent's perception regarding different CSR factors which included economic, legal, ethical, environmental responsibilities of the business. The respondents were supposed to indicate at what extent they agreed to the statements that defined CSR determinants.

Based on the results, the understanding of CSR among respondents was assessed as high $(68 \%)$, their readiness to know more about CSR was relatively high-72.5\%. The results are presented on table 1.

The majority of the respondents strongly agree that the highest impact on employer attractiveness has Legal factors, followed by Ethical, Environmental, Philanthropic and then Economic factors.

\begin{tabular}{|l|l|l|l|l|l|l|l|l|}
\hline & Legal Responsibility & SA & A & N & D & SD & TOT & Mean \\
\hline $\mathbf{1}$ & $\begin{array}{l}\text { Company should arrange suitable } \\
\text { health, safety and welfare conditions. }\end{array}$ & 192 & 8 & 0 & 0 & 0 & 200 & $\mathbf{4 . 9 6}$ \\
\hline $\mathbf{2}$ & $\begin{array}{l}\text { The business should comply with } \\
\text { legal standards and regulations in } \\
\text { business decisions. }\end{array}$ & 170 & 20 & 8 & 2 & 0 & 200 & $\mathbf{4 . 7 9}$ \\
\hline $\mathbf{3}$ & $\begin{array}{l}\text { The business needs to minimize nega- } \\
\text { tive effects on the local society. }\end{array}$ & 160 & 27 & 10 & 3 & 0 & 200 & $\mathbf{4 . 7 2}$ \\
\hline
\end{tabular}




\begin{tabular}{|c|c|c|c|c|c|c|c|c|}
\hline 4 & $\begin{array}{l}\text { The company should offer employees } \\
\text { good work-life balance. }\end{array}$ & 125 & 63 & 11 & 1 & 0 & 200 & 4.56 \\
\hline 5 & $\begin{array}{l}\text { There must be a clear policy against } \\
\text { all forms of discrimination in the } \\
\text { workplace. }\end{array}$ & 103 & 65 & 24 & 8 & 0 & 200 & 4.31 \\
\hline & Grand Mean & & & & & & & 4.67 \\
\hline & Ethical Responsibility & & & & & & & \\
\hline 1 & $\begin{array}{l}\text { Business should develop employees' } \\
\text { skills by offering them training and } \\
\text { educational activities. }\end{array}$ & 162 & 28 & 8 & 2 & 0 & 200 & 4.75 \\
\hline 2 & $\begin{array}{l}\text { The company should take into ac- } \\
\text { count employees' interests in the } \\
\text { decision-making process }\end{array}$ & 134 & 52 & 12 & 2 & 0 & 200 & 4.59 \\
\hline 3 & $\begin{array}{l}\text { The company should ensure timely } \\
\text { payment for the suppliers. }\end{array}$ & 134 & 42 & 22 & 2 & 0 & 200 & 4.54 \\
\hline 4 & $\begin{array}{l}\text { The management attitude toward } \\
\text { employees is very important at wor- } \\
\text { kplace. }\end{array}$ & 120 & 52 & 25 & 3 & 0 & 200 & 4.44 \\
\hline 5 & $\begin{array}{l}\text { If there were more ethical companies, } \\
\text { life would be better }\end{array}$ & 79 & 73 & 31 & 10 & 7 & 200 & 4.03 \\
\hline & Grand Mean & & & & & & & 4.47 \\
\hline & Environment Responsibility & & & & & & & \\
\hline 1 & $\begin{array}{l}\text { Business should think of operational } \\
\text { cost savings (paper saving, less plastic } \\
\text { usage etc.) }\end{array}$ & 143 & 44 & 13 & 0 & 0 & 200 & 4.65 \\
\hline 2 & $\begin{array}{l}\text { The business should comply with en- } \\
\text { vironmental standards and regulations } \\
\text { in business decisions. }\end{array}$ & 134 & 54 & 12 & 0 & 0 & 200 & 4.61 \\
\hline 3 & $\begin{array}{l}\text { In the workplace, there should be } \\
\text { clear policy regarding pollution, } \\
\text { recycling, waste minimization, energy } \\
\text { consumption. }\end{array}$ & 134 & 57 & 7 & 2 & 0 & 200 & 4.61 \\
\hline 4 & $\begin{array}{l}\text { The business should consider poten- } \\
\text { tial environmental impacts when they } \\
\text { are developing new products. }\end{array}$ & 114 & 43 & 26 & 17 & 0 & 200 & 4.27 \\
\hline 5 & $\begin{array}{l}\text { I would reject a job offer if the } \\
\text { business operates without respect to } \\
\text { the environment }\end{array}$ & 32 & 52 & 62 & 47 & 7 & 200 & 3.27 \\
\hline & Grand Mean & & & & & & & 4.28 \\
\hline & Philanthropic Responsibility & & & & & & & \\
\hline 1 & $\begin{array}{l}\text { The companies should give some } \\
\text { educational activities and training to } \\
\text { the society. }\end{array}$ & 143 & 44 & 13 & 0 & 0 & 200 & 4.65 \\
\hline 2 & $\begin{array}{l}\text { The business needs to think on } \\
\text { well-being of the society. }\end{array}$ & 134 & 53 & 12 & 2 & 0 & 200 & 4.61 \\
\hline
\end{tabular}




\begin{tabular}{|c|c|c|c|c|c|c|c|c|}
\hline 3 & $\begin{array}{l}\text { The company's obligation is to think } \\
\text { about sustainable development. }\end{array}$ & 135 & 52 & 11 & 2 & 0 & 200 & 4.6 \\
\hline 4 & $\begin{array}{l}\text { Charity events, some donations and } \\
\text { employee volunteering. }\end{array}$ & 72 & 58 & 65 & 5 & 0 & 200 & 3.98 \\
\hline \multirow[t]{3}{*}{5} & $\begin{array}{l}\text { CSR is one of the best way to attract } \\
\text { and attain staff in the company. }\end{array}$ & 45 & 87 & 60 & 7 & 1 & 200 & 3.84 \\
\hline & Grand Mean & & & & & & & 4.33 \\
\hline & Economic Responsibility & & & & & & & \\
\hline 1 & $\begin{array}{l}\text { I would like to work for the company } \\
\text { which is financially stable. }\end{array}$ & 121 & 63 & 16 & 0 & 0 & 200 & 4.52 \\
\hline 2 & $\begin{array}{l}\text { Fair compensation for the employees } \\
\text { and some bonusses. }\end{array}$ & 120 & 48 & 27 & 5 & 0 & 200 & 4.41 \\
\hline 3 & $\begin{array}{l}\text { For the companies, top priority must } \\
\text { be financial responsibilities toward its } \\
\text { investores. }\end{array}$ & 20 & 73 & 76 & 22 & 9 & 200 & 3.36 \\
\hline 4 & $\begin{array}{l}\text { Companies should focus on the main } \\
\text { objective, which is to generate profit. }\end{array}$ & 32 & 23 & 102 & 35 & 8 & 200 & 2.87 \\
\hline & Grand Mean & & & & & & & 3.79 \\
\hline
\end{tabular}

Table 1: CSR factors and CSR determinants on employer attractiveness

Source :According to own questionnaire, $n=200$

The ultimate importance of legal dimension is that people firstly seek safe and healthy place to work, the workplace where they will make balance with work and life. Legal responsibility ensures that business fulfills its responsibility to obey the laws and other regulations. It can be wide range of legislation that a business needs to comply with, for example employment, competition, safety and health etc. Meeting legal requirements and contribution to a better society can influence on the choice of job choosing.

Regarding the Ethical responsibility of the business, respondents indicate that one of the top priority for the organization should be training and development opportunity for the employees and their involvement in the decision-making process. Ethical responsibility for the business simply means to do right things, to act morally and ethically, go beyond precisely what the law requires, in terms of how you treat your employees, and how the business sets up working conditions.

Under Environmental responsibility of the business, the respondents consider that business should think about operational cost savings(paper savings, less plastic usage etc.) and should comply with environmental standards and regulations in business decision. This type of responsibility has a crucial effect on employer attractiveness, so that CSR is the way how the companies achieve their commercial success with ethical values, respect people and community and natural environment in order to keep the sustainability. 
In Philanthropic responsibility, respondents mention that business should think on the well-being of the society. This is why business goes beyond acting legally, ethically, starts to give back to the society, like working on a project which is related to the well-being of a society, charitable donations, supporting some sport activity etc.

Under Economic responsibility, the respondents express positively that they would like to work for financially stable company. Moreover, among economic factors, fair compensation to the employees comes one of the priority for job seekers. Before the business start doing some clever activities, the business first must make a profit. The business can survive in the society if it is profitable, if it can pay debt and pay wages. In other words, economic responsibility is the foundation of the business.

These findings have some connection with the previous studies that have found a correlation between company Corporate Social Responsibility and employer attractiveness. A study done by Greening and Turban (2000) on CSR and organizational attractiveness have found that prospective employees prefer to find a job in the company, that is socially responsible rather than the company which has poor CSR image. The studies done around the topic have proved that CSR positively affects on the company and attracts people from outside. Today, more companies trying to pay attention on the world concern and putting CSR activities in their strategic plan.

Below on the chart you can find different factors in the chart, for example compensation, work-life balance, brand recognition and reputation, personal development factors, career growth opportunity etc. which define job attractiveness for the employees/job seekers. Based on the results i got, the most important job attractiveness determinant is career growth opportunity, that indicates that the business sholud focus on the employees' career progress. Then was followed work-life balance. As it turned out the job which fits on employees' interests and personality is one of the key factor in regards of employer attractiveness. Fair compensation was ranked as one of the highest as well. CSR image and brand reputation got 4.0 mean, which indicates that it can be one of the strong determinant in the job choice so that companies must pay attention on their action to the society and on the environment. 


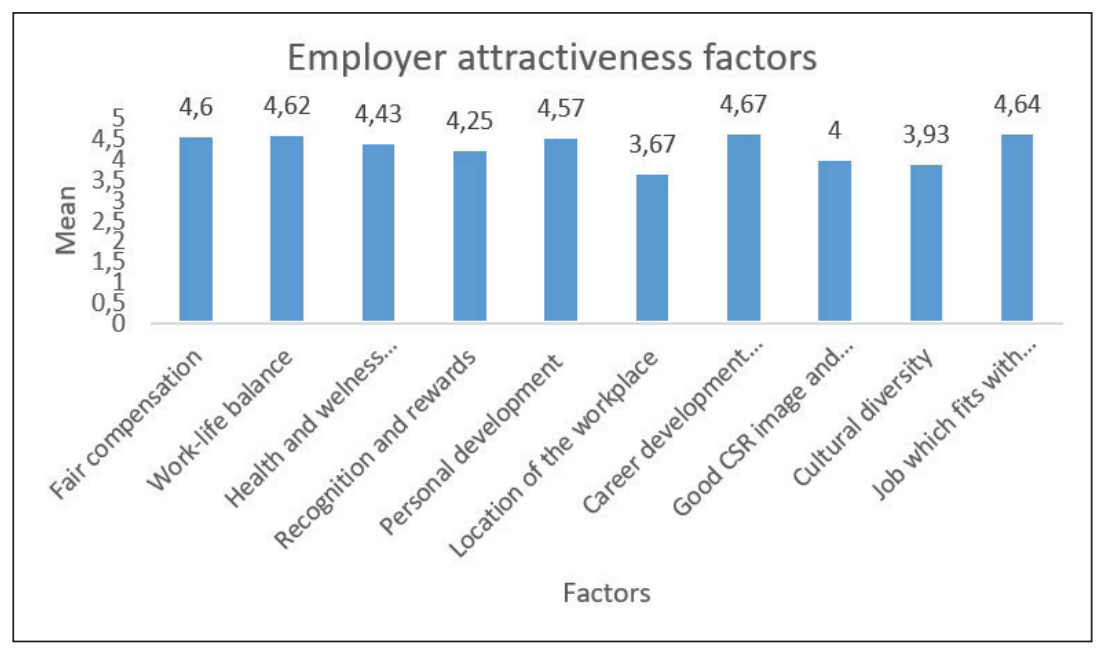

Table 2: Job satisfaction determinants

Source: According to own research. $n=200$

\section{Conclusions}

To draw a conclusion of this research paper, the quota of Cooney would summarize the results to some extent: The next generation of employees is seeking out employers that are focused on the triple bottom line: People, planet and revenue.

The main research question „How CSR based factors influence on employer attractiveness and how these factors impact on the choice of employees in choosing a workplace" can be answered as partly. To what extent CSR can be considered as the strongest tool for attracting new talents in the organization and keeping them for a long period is difficult to be measured. According to the results, CSR dimensions (economic, social and environment) were measured by the respondents as highly important for an organization. Respondents have agreed that CSR can give the business competitive advantage. Employees have agreed that it is business's responsibility to think about the environment it affects and moreover it is business's responsibility to think about the community and society wider. However, the paper shows that there is not straight forward answer to what extent CSR can have an influence on employer attractiveness. Taking into consideration other determinants on employer attractiveness, CSR alone can not attract and attain talents in the organization, but can be one of the strongest determinant that would attract people from outside and could encourage workers to stay committed to the organization. 
Study recommends that organizations should put CSR policies in the place and try to communicate it to the employees, and not only to employees, to the society as well because CSR can have contagious effect, positive signals should spread into the society in order to encourage other business to follow on their path. Study showed us that $90 \%$ of the respondents agreed that CSR makes the company more competiive in the market.

\section{Acknowledgements}

I gratefully acknowledge the support of Ministry of Human Resources, National Talent Program with project number: NTP-HHTDK-18-0068 without which the present study could not have been completed.

\section{References}

[1] Archie B. Carroll, (1991) The Pyramid of Corporate Social Responsibility: Toward the Moral Management of Organizational Stakeholders' 34:4 Business Horizons 39, 40, 41;

[2] Bauman W., Skitka L., (2012). Corporate social responsibility as a source of employee satisfaction. Research in Organizational Behavior Volume 32, 2012, Pages 63-86;

[3] Benedek, A., (2017): A stratégiai CSR személyiségi gyökerei. Vállalkozásfejlesztés a XXI. században : VII. tanulmánykötet Budapest pp. 55-69. , 15 p.

http://kgk.uni-obuda.hu/sites/default/files/04_BenedekAndrea.pdf Benedek, A., Takács-[4] György K. (2014): Responsible Management in the Framework of Market Economy. International Journal of Contemporary Management, 13(3), 8-20.

http://ejournals.eu/sj/index.php/IJCM/article/viewFile/4284/4218

[5] Gonzalez-Rodriguez, R., Diaz-Fernandez, C., Simonetti, B (2015). The social, economic and environmental dimensions of corporate social responsibility: The role played by consumers and potential entrepreneurs;

[6] Kiss A, Bekő L, Koncz G (2012): A fenntarthatóság alapvetéseinek vizsgálata Zalaszentgrót településen - társadalmi vonatkozások.In: Dinya, L; Némethy, S; Nyíri, A (szerk.) Zöld társadalom, zöld gazdaság, innováció.Gyöngyös, Magyarország: Károly Róbert Főiskola, pp. 93-96. 
[7] Kristin B., Backhaus Brett. A., Stone K., (2001)., Exploring the Relationship Between Corporate Social Performance and Employer Attractiveness. https://doi.org/10.1177/0007650302041003003;

[8] R. Hay., E. Gray., (1974) Social responsibilities of business management. Academy of Management Journal, 17(1), 135-143;

[9] Yusri Y., Amran A., (2012). CSR Towards Workplace and Human Resource Disclosure: Employees' Perspectives. Malaysian Accounting Review, Vol. 11 No. 2, 39-68;

[10] Brown, J.A. \& Forster, W.R. (2013). CSR and Stakeholder Theory: A Tale of Adam Smith. Journal of Business Ethics;

\section{Link of the research questionnaire:}

https:/docs.google.com/forms/d/e/1FAIpQLSeqy8bFx2dYRjrXW30VGs1WmL2O8HLzuBKt5KVxV4PqpoCPaA/viewform

\section{Authors:}

\section{Ana Potskhverashvili}

Faculty of Economics and Social Science, the specialization

in Business Development

ana.potskhverashvili1@gmail.com 